\title{
The Transmission System of Pottery Craftsmanship in the Context of Socio-Cultural Changes
}

\author{
Iriaji $^{1}$, Tjetjep Rohendi Rohidi ${ }^{2}$, Totok Sumaryanto $\mathrm{F}^{3}$, Dharsono Sony $\mathrm{K}^{4}$ \\ \{iriaji.fs@um.ac.id ${ }^{1}$,ttrohidi@yahoo.com², totokunnes@yahoo.co.id ${ }^{3}$ \} \\ Universitas Negeri Malang, Jl. Semarang no. 5 Malang $65145^{1}$ \\ Universitas Negeri Semarang, Kampus Sekaran Gunungpati, Semarang 502292,3
}

\begin{abstract}
The fact reveals that there are several differences in the transmission system applied among the pottery craftsmen as viewed from the cultural changes phenomena. In regards to the background above, this study aims at analyzing the socio-cultural characteristic and the transmission system of pottery craftsmanship in Pagelaran. Methodologically, this research utilized qualitative approach through phenomenologist research design as well as theoretical approach with socio cultural and arts education theory. The techniques used in collecting the data were thorough interviews, observations, literature reviews, with the researcher as the key instrument. The data were analyzed through interactive analysis model and paradigmatic theory analysis. This research brought out several findings: first, the characteristic of the pottery craftsman in Pagelaran is close to the local Malangan culture. Second, there are two concepts of transmission system discovered in the research, those are parental succession system and apprentice system. This finding may serve as the government's reference in formulating policy or conservation program as the means to preserve and to develop the local cultural arts.
\end{abstract}

Keywords: influencing system, art education, pottery craftsmanship

\section{Introduction}

In Indonesia, pottery craftsmanship is found in various regions, such as those developed in Kasongan of Yogyakarta, Galogandang of Western Sumatra, Pleret of Western Java, Pejaten of Bali, Dinoyo of Malang, Banyumulek of Western Lombok, Panunjak of Central Lombok, and in some other locations of Indonesia. Meanwhile, especially in Malang region, there are three centers of pottery craftsmanship that still survived and developed, those are: (1) pottery village of Pagelaran, Pagelaran District, Malang Regency; (2) pottery village of Glanggang, Pakisaji District, Malang Regency; and (3) pottery village of Penanggungan, Dinoyo District, Malang City [1]. The three centers of pottery in Malang Region, although all of them are producing pottery, each of them have different cultural expression that is seen from the differences of characteristics of the shapes, techniques, as well as functions of the pottery produced.

In the perspective of socio-culture, basically, every group of society (including the pottery group of society) has the characteristics that are continuous and dynamic according to the development of era. In [2] mentioned that in every life of human being, as individual or community, sooner or later changes will appear according to the development of economy, socio-culture, politics, and science and technology. Nothing on this world that is unchanged except the change itself. It is also mentioned by [3]; [4]; and [5] with the praxis concept which 
mentioned that human being can shape the symbols of life of socio-culture reciprocally between the praxes and the objective structure that can create the continuity as well as transformation.

The proof that every group of society always experience the process of continuity and the transformation can be seen from various result of the research in pottery of Kasongan [6], Banyumelek [7], Bayat [8], Dinoyo [9], Bali [10], Mayong Lor [11], and Mambang-Jombang [12] mentioned the presence of characteristics of continuity and the transformation in protecting and continuing the tradition of the pottery life. This also happens on the pottery life of other countries such as Southern Africa and Zimbabwe. Based in the result of analysis for the social and technological aspect, the pottery of Southern Africa and Zimbabwe experienced the continuity and transformation in term of production technique. It is proven after the result of material laboratory research is found [13]. In China, the same case is also found. The history of the development of Chinese pottery experienced significant changes in term of shapes, meaning and function of pottery [14].

The society of Pagelaran village, as how a traditional society commonly be, used to have a strong social relationship bond, since they possess similar bloodline, domicile, and profession. Yet, the the current globalization era, the type of social relationship among the society start to change. The society of Pagelaran village begin to be influenced by the mindset of modern society who are more rational and innovative. Such socio-cultural attitude may affect the transmission system among the community of pottery craftmen in Pagelaran Village in their way to transfer the knowledge, skill, and phylosophical values of craftsmanship from one generation to the next generations. In [15], [16], [17], [18], [19], [20], and [21] explained that arts transmission system is a form of arts education in the society that may occur through parental succession system, apprentice system, studio system, and academic system. In this case, there is a correlation between the socio-cultural situation experienced by the pottery craftsmen community with the type of transmission system applied in transmitting the skill in pottery.

According to the empirical data and theory analysis above, the researcher managed to identify several intiguing issues that is urgent to be studied: (1) among the development era of economy, social, culture, politic, and science sectors, Pageralan pottery still exists and possess a unique tradition and socio-cultural characteristic that build the cultural expression of the society; and (2) the community of pottery craftsmen have their own transmission system in order to transfer the knowledge, skill, and phylosophical values of pottery from generations to generations. Therefore, a study is necessary to be conducted to analyze them.

\section{Methods}

According to the research question proposed, that is about the life phenomena of pottery of Pagelaran Village of Malang Regency deeply is the reason qualitative approach is needed. In a more operational method, the phenomenology research design is used, that is to understand deeper the meaning of phenomena in the daily life, interpreting the experiences, and knowledges of research subject in the interaction see ([18] and [19]). The research design of phenomenology Emphasize more to the multi-perspective and intersubjective [24]. Multi-perspective means to use various perspectives, so that it will sharpen the discovery of the object. Meanwhile, intersubjective means an attempt to be inside the conceptual world of all the subjects researched.

The field data is gained through the in depth interviews, observation and document study with the researcher as the key instrument. The use of observation technique in this research is meant to observe the socio-culture environment and the physical environment surrounding the 
pottery craftsmen. The use of depth interviews technique meant to various information in term of the characteristics of socio-culture and the influencing system. The interviewees referred are: individual or community of society of pottery craftsmen, the local public figures, local cultural expert, local pottery expert, and the related institution. The document study method is done to search for the written document and the archive about pottery craftsmanship in the Pagelaran Village. In order to guarantee the validity of the data, triangulation is used, those are: the triangulation of source, methodology, and theory [23] and [24]. The analysis model used are: (1) interactive analysis model, (2) interpretive analysis model, and (3) analysis model of paradigmatic theory (see [25]). The data analysis is done through the steps of data collecting, data reduction, data presentation, and the conclusion drawing/verification, as well as finding out concepts of influencing system in Pagelaran Pottery craftsmanship in the Pagelaran Village using the theory analysis of paradigmatic.

\section{Results and Discussion}

\subsection{The Characteristics of Socio-culture of the Pagelaran Society}

The findings indicated that the life attitude of socio-culture of society in the pottery center of Pagelaran is based on the original culture of Javanese, local wisdom of Malangan, Jawa Mataraman, and the teaching of Islam as the unity that complement each other's. In [26] mentioned that such acculturation is called Javanese Islam.

One of the unique tradition from the acculturation is the values of Javanese Islam in the community of pottery craftsmanship of Pagelaran is the event of "selamatan" in celebrating Maulud Nabi that is known as the tradition of "guak ajang". The guak ajang tradition is a tradition of throwing a bowl called cowek in front of the front door of the house until it breaks. This tradition is done after the content of ambengan or the fruits are brought home from the event, and they replace the food to another container. This tradition, selamatan, is what encourage the development of pottery in Pagelaran Village.

The public figure (during the FGD on August $25^{\text {th }} 2018$ ) stated that the name of Geta'an Village originally came from Maulud Nabi event conducted by the people in Pagelaran Village annually, continuously from generation to generation. In preparing Maulud Nabi event, the people prepared various kinds of "ubo rampe" or foods for selamatan that requires to be placed on pottery container. Due to the vent, the production of pottery in Geta'an Village Dukuh Krajan increases rapidly that the place is finally called as geta'an Village. This name is taken from the trerm ' $g e t a$ ' which means pottery.

The people in in Pagelaran Village live by the culture of Malangan who tends to be democratic, open, and humble. It is reflected from their daily social life when the people of Pagelaran Village tend to be "blak-blakan" (straightforward) and willing accept other people's opinion, even though it is different from theirs. In regards to stratification, the people in Pagelaran Village are indifferent towards the high level or low level of society. As [27] and [28] supported that the culture of Arek or Malangan is known to have the values of being democratic, open, expressive, egaliterian, bloko endi (humble) and not preferring ewuh pakewuh.

The pattern of economy life in Pagelaran Village refers to the lifestyle of Javanese people as Mr. Sukardi, a public figure, said, "ngenani perkawis penda-melan, tiang desa mriki rumiyen roto-roto mboten ngoyo, sak wontene, sing penting tekun, dilakoni, lan sedoyo ingkang sampun dilakoni dipun pasrah-aken malih dateng Kersane Gusti Alloh ingkang nyukani rejeki" ( in 
respect to jobs, commonly, the people in the village do not have any ambition, all that matters for them is just do it diligently, and they leave all the result of their work to Almighty Allah, who bless them). As [29] mentioned that Javanese people live their live in a simple, humble, non- ambitious way and just let everything flow.

Generally, the socio-cultural life of Pagelaran people can be calssified as follows: (1) those who rely on pottery making as their main resources since they think it is easy to do and relatively enough to cover their daily expenses; (2) the attitude of "nrimo" or grateful is their motivation to preserve their work; (3) in social-religious perspective, pottery products are still needed by Pagelaran people in order to fulfill the ceremonial equipment like in selamatan or merely for kitchen tools; (4) the preservation of pottery tradition through inheriting the tradition to the next generation is still considered compulsory by the parents, the craftsmen of Pagelaran pottery; and (5) the attitude of Malangan culture acts as the foundation of their perspective to emrace the change and willing to adjust with the development of technology and consumer's taste.

\subsection{The transmission System of Pottery Crafts-manship in Pagelaran: The representation of Arts Education}

The culture of pottery in Pagelaran Village has been developed that it generated two types of influencing system: (1) influencing system to traditional pottery craftsmen; and (2) influencing system to the community of creative pottery craftsmen. In the perspective of arts education, the influencing system applied by the traditional pottery craftsmen is categorized as parental succession system, that is the transfer of ability of craftsmanship (knowledge, skill, and values) from the parents to their biological children. While the influencing system in the community of creative pottery craftsmen is categorized as apprentice system in which a craftsmen transfer their ability of craftsmanship (knowledge, skill, and values) to someone else's children who is interested or talented (see [19], [20], [30], [31]).

The influencing system among the craftsmen community of traditional pottery usually take place in the family setting where the parents act as the teacher and the biological children as the learners. Meanwhile, the influencing system on the creative pottery craftsmen community is held by the Technical Implementation Unit of Pottery Training Center, University, Disperindag, regional government that cooperating with the craftsmen community. Educator/trainer involves experienced instructor or craftsmen, while the internship are craftsmen who have the talent, interest, and motivation.

The learning process in the craftsmen community of traditional pottery implemented apprenticeship approach where the parents require the children to directly observe and practice by following the steps in craftsmanship process in making pottery that is exhibited by the parents. While for the children's comprehension regarding the values or philosophy of pottery is acquired during the process of pottery production practice. Operationally, the training is supported by the method of: demonstration, imitation, drilling, and recitation along with unstructured information delivery. While for the learning process in the craftsmen community of creative pottery, they apply academic approach which begin with the instructor explained about the goals of work activity, the theory of pottery production using the latest technology, continued with the practice training according to the theory learned, and finally the result will be evaluated. Operationally, this apprentice system is supported by various lecturing system, imitation method, recitation method, drilling method, and organized workflow.

In Pagelaran Village, the materials are presented during the inheritance process by the parents, including with the material category with procedure-motoric type, that is material in terms of procedural steps in craftsmanship by following certain pattern and containing a certain 
related meaning so that it tends to shape a static craftsmanship. Such material is delivered as the craftsmanship practice that is related to the activity of socio-culture in its environment and is not an art practice privately. Meanwhile, the materials presented in the internship program on the creative pottery craftsmen is the material of motoric craftsman type, that is in the form of explanation or written module that is given to the interns. Besides, it is also using the motoric typed material, that is the step by step procedure of practice of pottery production with the new technology that gives the interns to have the mental skill that is conditional in a sense of able to face the challenge of changes.

The components are basically resulted on the achievement of the goal. The establishment of inheritance system of the parents is aimed to create pottery apprentices who can be the successor of their parents. Meanwhile, the establishment of internship system is not merely as the successors of their parents, yet to create the next generation of pottery craftsmen with the mindset that is innovative, creative, and willing to grow along with the needs of the market and taste of consumers.

\section{Conclusion}

Based on the empirical facts in the findings above, it can be concluded that there are two concepts of influencing system in Pagelaran Pottery as the representation of arts education among the society, those are influencing system in the craftsmen community of traditional pottery through inheritance method from the parents to the children, and influencing system in the craftsmen community of creative pottery through apprentice method. These findings in respect to the influencing system may serve as the reference in formulating strategies or policies for either conservation program or development program. Besides, it can also be made as coaching and/or training to preserve and maintain the continuity of Pagelaran pottery. In regards to formal education, these findings may serve as the foundation to build a cooperation between the pottery craftsmen and the surrounding school, along with the support from the Department of Education, to form a synergy relationship in order to conduct collaborative arts education that allow students to engage with the local culture in their surroundings. In hope, it could develop the students' creativity and appreciation. 


\section{References}

[1] Iriaji, "Identifikasi Karakteristik Visual, Teknik dan Makna Simbolik Kriya Gerabah di desa Pagelaran Kabupaten Malang sebagai Sumber Belajar Berbasis Kearifan Lokal," Fakultas Sastra Universitas Negeri Malang, Malang, 2017.

[2] T. R. Rohidi, "Kesenian Tradisional 'Nusantara' Bahasan tentang Warisan dalam Konteks Perubahan Budaya,” Pascasarjana Universitas Negeri Makasar, Makasar, 2016.

[3] W. J. V. Muelen S. J., Ilmu Sejarah Filsafat. Yogyakarta: Kanisius, 1987.

[4] T. Asad, "Anthropological conceptions of religion: Reflections on Geertz," "Man," vol. 18, no. 2, pp. 237-259, 1983.

[5] P. Bourdieu, Outline of Theory of Practice. Cambridge, England. Cambridge, England: Cambridge University Press: Cambridge University Press, 1977.

[6] M. Sumarno, “'Tingkat adopsi Inovasi Teknologi Pengusaha Sentra Industri Kecil Kerajinan Gerabah Kasongan Kabupaten Bantul,'” dalam jurnal Manajemen dan Kewirausahaan, vol. 12, no. 1, pp. 1-10, 2010.

[7] P. Muka and Berata, Gerabah Banyumulek satu Tinjauan Budaya. laporan penelitian DIPA ISI Denpasar. Denpasar: FSRD ISI Denpasar, 2009.

[8] P. Yustana, "Bayat Ceramic (Aesthetic Form, and Function)," Jurnal Penelitian Seni Budaya, vol. 6, no. 1, Jun. 2014.

[9] Ponimin, "Keramik Dinoyo Malang Kontinuitas dan Perubahannya," tesis Program Pascasarjana UGM, UGM, Yogyakarta, 2001.

[10] Pandanwangi, "Potensi Pengembangan Gerabah Bali dan Dampaknya pada Pemenuhan Kebutuhan Pariwisata di Bali: Studi Kasus Gerabah Desa Adat Kapal, Kecamatan Mengwi, Kabupaten Badung-Bali,” tesis, Program Studi Seni Rupa Murni FSRD Universitas Kristen Maranatha, Bandung, 2001.

[11] T. Triyanto, "Ceramics Enculturation of Artisans' Community in Mayong Lor Village: Adaptation Strategies in The Preservation and Continuation of Local Culture Creative Potential," The Journal of Educational Development, vol. 3, no. 2, pp. 98-105, 2015.

[12] A. Suhariyanto, "Gerabah Mambang Jombang: Tradisi Prasejarah Yang Masih Berlangsung Sampai Sekarang Sebagai Wujud Enkulturasi," Skripsi, Program Studi Pendidikan Sejarah, Jurusan Sejarah, Fakultas Ilmu Sosial, Universitas Negeri Malang, Malang, 2014.

[13] A. Lindahl and I. Pikirayi, "Ceramics and Change: An Overview of Pottery Production Techniques in Northern South Africa and Eastern Zimbabwe During the First and Second Millennium AD," Archaeol Anthropol Sci, vol. 2, no. 3, pp. 133-149, Sep. 2010.

[14] X. Lin and J. Xie, "Interpretation of the Symbol of Ancient Chinese Pottery," in Soft Computing in Information Communication Technology, Springer, Berlin, Heidelberg, 2012, pp. 33-37.

[15] A. Bisin and T. Verdier, The Economics of Cultural Transmission and Socialization. editors Benhabib, J., et al. Handbook of Social Economics, vol. 1A. The Netherlands: North-Holland, 2011.

[16] N. Claidière and J. B. André, The Transmission of Genes and Culture: A Questionable Analogy. Springer Science and Business Media: LLC 2011, 2011.

[17] N. T. Rahayu and dkk., "Model Pewarisan Nilai-Nilai Budaya Jawa Melalui Pemanfaatan Upacara Ritual,” Jurnal Ilmu Komunikasi, vol. 12, no. 1, pp. 55-69, 2014.

[18] R. T. Hosfield, "Modes of Transmission and Material Culture Patterns in Craft Skill," in Pattern and Process in Culture Evolution. Origins of Human Behavior and Culture, 2nd ed., Berkeley: University of California Press, 2009, pp. 45-60.

[19] Soehardjo, Pendidikan Seni, dari Konsep sampai Program (Buku I). Malang: Bayumedia Publishing, 2011.

[20] R. N. Wilson, The arts in society. New York: Arno Press, 1979.

[21] M. Jazuli, . “'Model Pewarisan Kompetensi Dalang,”’ Jurnal Harmonia, vol. 11, no. 1, pp. 85-99, Jun. 2011

[22] J. W. Creswell, Qualitative Inquiry and Research Design: Choosing Among Five Approaches. Terjemahan oleh Ahmad Lintang Lazuardi. Yogyakarta: Pustaka Pelajar, 2015. 
[23] L. J. Moleong, Metodologi Penelitian Kualitatif. Bandung: PT Remaja Rosdakarya, 2000.

[24] H. Sutopo, Metodologi Penelitian Kualitatif Dasar Teori dan Terapannya dalam Penelitian. Surakarta: Sebelas Maret University Press, 2002.

[25] M. B. Miles and A. M. Huberman, Analisis Data Kualitatif. Terjemahan Tjetjep Rohendi Rohidi. Jakarta: Penerbit Universitas Indonesia (UI-Press), 1992.

[26] C. Geertz, Kebudayaan dan Agama, 3rd ed. Yogyakarta: Kanisius, 1995.

[27] A. Abdillah, "Budaya Arek Suroboyo," Tesis S-2, Pascasarjana Universitas Airlangga, Surabaya, 2007.

[28] N. Leni, “Demokrasi dan Budaya Politik Lokal di Jawa Timur menurut R. Zuhro, dkk,” Jurnal TAPIs, vol. Vol.8, No.1 Januari-Juni 2012, 2012.

[29] Moh. Roqib, Harmonisasi dalam Budaya Jawa, 1st ed. Purwokerto: STAIN Purwokerto Press, 2007.

[30] T. Ph. D. Struck, F., Vocational Education for a Changing World. New York: Wiley and Sons.: Wiley and Sons., 1945.

[31] L. L. Cavalli-Sforza and M. W. Feldman, Cultural transmission and evolution: a quantitative approach. Princeton, N.J: Princeton University Press, 1981. 